\title{
Exploration of Entrepreneurial Intentions of Management Students Using Shapero's Model
}

\author{
Vivek Ranga1, Shweta Jain ${ }^{2}$, P. Venkateswarlu ${ }^{3}$ \\ ${ }^{1}$ ICFAI Business School (IBS), Ahmedabad, India \\ ${ }^{2}$ ICFAI University Jaipur, Jaipur, India \\ ${ }^{3}$ ICFAI Business School (IBS), Hyderabad, India \\ Email: vivekr@ibsindia.org, sjain@iujaipur.edu.in, venkat@ibsindia.org
}

How to cite this paper: Ranga, V., Jain, S. and Venkateswarlu, P. (2019) Exploration of Entrepreneurial Intentions of Management Students Using Shapero's Model. Theoretical Economics Letters, 9, 959-972. https://doi.org/10.4236/tel.2019.94062

Received: February 10, 2019

Accepted: April 19, 2019

Published: April 22, 2019

Copyright $\odot 2019$ by author(s) and Scientific Research Publishing Inc. This work is licensed under the Creative Commons Attribution International License (CC BY 4.0).

http://creativecommons.org/licenses/by/4.0/

\begin{abstract}
This study was conceived as an attempt to explore the entrepreneurial intentions of management scholars with the objective to ascertain the contribution of selected variables in shaping and defining the entrepreneurial intentions of these students. For the same reason, Shapero's model for explaining the entrepreneurial intentions was applied on the students studying the management program in a business school at Ahmedabad. The model was based on three fundamental variables as perceived feasibility, perceived desirability and propensity to act. Data collection was made through a questionnaire and analyzed for descriptive statistics and partial least squares regression analysis using SPSS. As the study was primarily directed towards the students pursuing management program, important conclusions pertaining to the entrepreneurial intentions of these students were drawn using Shapero's model as the key premise. Among the three independent variables, perceived desirability was identified to have significant contribution to the entrepreneurial intentions followed by perceived feasibility. The study indicated that students were enthusiastic about becoming entrepreneurs and believed that being entrepreneurs positively brings in a larger sense of gratification. A course on entrepreneurship with specialized modules if introduced, is expected to create interest and develop their attitude towards business. These modules would also enhance the entrepreneurial skills of the students.
\end{abstract}

\section{Keywords}

Shapero \& Sokol Model of Entrepreneurial Event, Perceived Feasibility, Perceived Desirability, Propensity to Act, Partial Least Squares (SEM) Regression

\section{Introduction}

Entrepreneurship, as the term is generally understood, is venturing into a busi- 
ness activity driven by the ambition and acumen to translate one's idea into a commercial set-up. Defining the same from an economist's perspective, entrepreneurs are better understood as individuals who mobilize various resources, tangible as well as intangible, to establish and operate potential profitable ventures, actuated by their business acumen and risk taking propensity. Entrepreneurship in essence, is capitalizing upon an innovation and accordingly deploying essential resources to undertake a business endeavor, assuming the allied risks and rewards. Entrepreneurship is characterized by the astute and readiness to anticipate and address the risks that accompany these opportunities.

The challenges in terms of market uncertainties, regulatory obligations and financing quandaries serve as major bottlenecks. Steering through the tests and trials of the market, addressing the bureaucratic glitches and responding to the unrestrained dynamics of global business environments, demands high level of endurance and risk taking ability.

Ambition, enterprise and providence drive individuals to embark upon entrepreneurial initiatives, as the prospects for drawing one's identity as an achiever, being one's own boss and above all, making wealth, serve as catalysts to the entrepreneurial intents. At the same time, the potential downside of losing on multiple fronts compounds the vulnerability, as not all entrepreneurial ventures are destined to become success stories.

Despite all risks and liabilities, Entrepreneurship is vital to the socio-economic health of any country. Entrepreneurs serve as the drivers for a prospering economy, and the contribution is manifold. Entrepreneurial activities stimulate socio-economic development through multiple channels, be it in terms of innovation that leads to enhancing the quality of life for larger public by means of superior products and services, creating job opportunities at various levels and above all contributing through wealth generation. Entrepreneurial initiatives invite public investment and in turn maximize the wealth for larger set of investors. With the establishment of these businesses and industries, particularly in semi urban and rural areas, the fundamental infrastructure and public services witness enhancement, leading to inclusive growth and improved standard of living.

In larger context, with the increase in Total Entrepreneurial Activity (TEA) Index of a country, there is a proportionate growth in gross national income, self-sufficiency and above all, minimization of dependency on imports. These establishments invite investment and employment opportunities, serving a larger purpose. The Government in recent times has repeatedly acknowledged and emphasized on the much significant role of entrepreneurs and entrepreneurial establishments in the overall growth of the country. Entrepreneurship is vital for the sustained, scalable and inclusive growth of economy. For the same reason, several promising initiatives like Make in India and Startup India have been ambitiously launched and aggressively promoted. For a fast developing country like India, fortified with population in the range of 25 to 35 years has the potential and possibilities to capitalize upon the energy, enthusiasm and innovativeness of 
the young populace is tremendous.

In view of the growing emphasis to develop an inclusive and sustainable economic framework, the need to promote entrepreneurs and entrepreneurship is imperative. The overall macro environment essentially needs to be conducive and growth-oriented to leverage upon the available talent, innovation and cutting edge technology. In the same context, attempts to analyze and ascertain the relevant factors that stimulate and shore up the entrepreneurial intentions amongst the young populace can be considered valid and pertinent. This study was conceived with the same intent, and for that reason, Shapero's model for explaining the entrepreneurial intentions has been selected as the core premise.

With the key objective to identify the entrepreneurial intentions of the students in line with the Shapero \& Sokol model of Entrepreneurial Intentions, a set of students pursuing management program at one of the prominent institutes in Ahmedabad was selected for this study. The students at this institute included the ones in the $2^{\text {nd }}$ year of their management education, notably at the critical juncture of decision making as to whether take up entrepreneurship as career or opt for placement with any company. This has helped to ensure whether they possess entrepreneurial intentions or lack of any such intentions was expressed genuinely.

\section{Review of Literature}

A number of researchers and academicians have made attempts to identify a model that best describes and fits to explain the relationship of personal characters of individuals and their entrepreneurial intentions. Significant models were developed by [1] [2] [3] [4] [5]. Amongst the prominent ones, the three models that have been widely accepted and applied are, Ajzen, Shapero \& Sokol and Krueger models [6].

The Entrepreneurial Intentions have been studied to a large extent by two models namely Ajzen's Theory of Planned Behaviour (TPB) and Shapero and Sokol's model of Entrepreneurial Event (SEE). Behaviour was described as the function of three independent variables that are associated with the behavioural intentions by Azjen's Theory of Planned Behaviour. Ajzen identified the first independent variable, Personal Attitude as the influencing factor which he defined as the evaluation of the consequences of the behaviour, whether it is positive or negative. The second independent factor, the subjective norm describes the social and cultural pressure from families and relatives, if the individual will be able to perform the behaviour. The third independent variable influencing the intentions is the Perceived Behaviour Control, which represents the individual's capacity to perform the behaviour.

Entrepreneurial Intention is the characteristic of an individual, which means the desire or aspiration to do business. Azjen's definition [6] of intention corresponds to the amount of efforts any individual has put in, to behave in a specific manner or to display a specific behaviour. He opines that intention is the strongest variable that predicts the person's behaviour. To assess a person's be- 
haviour, it is very important to have the knowledge of their intention to carry out a specific behaviour.

Research has been conducted to identify what motivates individuals to do business. Starting a new business is not accidental or spontaneous; these actions for entrepreneurship are intentional. It is a purposive and intentional career choice [7] [8]. Krueger et al., added that it is very important for researchers or theoreticians to explain or develop models to identify the purpose or the reasons as to why large number of people make a decision to start their own business.

Ajzen conceptualized a model and explained the role and importance of the individuals' intentions in assessing the entrepreneurial intentions. He has proposed the model during the time when a lot of research was done using various models for determining the factors impacting the entrepreneurial intentions [9]. Two models viz. Ajzen's model of Theory of Planned Behaviour and Shapero \& Sokol model have subsequently become very popular [8]. Ajzen opined that attributes viz., attitude, subjective norm and perceived behaviour control have great influence on the individual's entrepreneurial intentions [6] [10] [11].

\section{The Shapero's Model}

Shapero's SEE model assumes that to start any new business or new venture, two components are very important, first the person proposing to do the business should have entrepreneurial intentions, termed as "credibility" and second that a new business or new venture requires some "event". It requires some extent of feasibility, desirability and propensity to act on the business opportunity [12].

As depicted in Figure 1, Shapero and Sokol Model of SEE is built on various aspects of cognitive behaviour framework. The major factors influencing an individual's intention to start a business are desirability, feasibility and propensity to act. He recognized that the changeable factors in this relationship are (i) Entrepreneurial Intentions as dependent variable which in this study pertains to the entrepreneurial behaviour of the management students at Ahmedabad; (ii) Perceived Desirability, Feasibility and Propensity to Act as independent variables. (1) Perceived feasibility is the extent of attraction people perceive, towards a specific; (2) Perceived Desirability is the positive or negative attitude and the

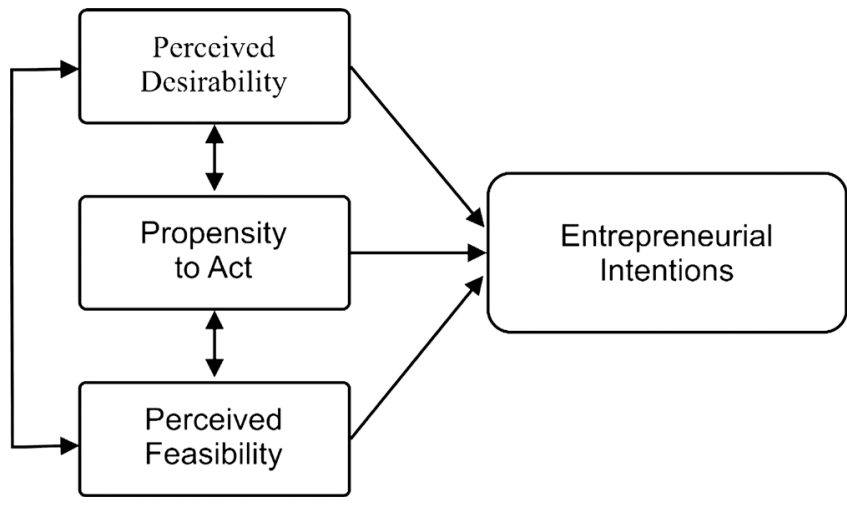

Figure 1. Model (Source: Shapero \& Sokol, 1982). 
perception of individuals capacity to perform a specific behaviour and (3) Propensity to Act is personal disposition to act on individuals' decisions that reflects willingness and intentions.

Shapero's model assumes that the entrepreneurial intentions require the potential for a specific activity to exist before its displacement, either positive or negative and inclination to act after the displacement [13].

Any entrepreneurial event is a combination of credibility, perceived feasibility, perceived desirability and perceived propensity to act. Shapero revealed that the behavioural intention formation is highly dependent on the perception of individuals towards entrepreneurship, actual business venture, and deliberate choice of a business option.

Entrepreneurial Venture Credibility: Shapero's model deals with the importance of persons' overall assessment pertaining to the credibility and propensity to perform a specific behaviour. As mentioned earlier, the person's intentions are mainly dependent on two factors credibility and propensity to act. The antecedents of credibility and propensity to act affect the behaviours towards entrepreneurial intentions or the actions of creating a business venture. The Shapero model accepts the case where an individual perceives creating a new venture as feasible and desirable and thus credible and such perceptions are likely to create intention to do business or start new business venture [14].

Perceived Desirability: In the context of Entrepreneurship, Perceived Desirability is the extent to which individuals find doing business is an attractive choice and is depicted by their desire to perform that behaviour in order to achieve the goal [2] [5]. It acts as a motivational factor that transforms attitude into entrepreneurial intentions [15]. Favourable attitude justifies favourable perceptions towards the specific behaviour of becoming an entrepreneur and the perceived desirability is related to Ajzen's attitude and subjective norm variables. In this case, social background, cultural and traditional influences, family, relatives and friends can influence the perceived desirability for entrepreneurship.

Perceived Feasibility: In the entrepreneurship context, Perceived Feasibility refers to the attitude of the individuals towards the feasibility of the specific behaviour required to become an entrepreneur. It also reflects the attitude regarding the persons' potential to do business in the form of competence [5] which is in line with Azjen's theory.

Propensity to Act. It is the personal disposition to act on individual's decisions that reflects willingness and intentions. Propensity to act is from the significant efforts of individuals and their desire and willingness to perform a specific behaviour that is starting a business venture [2] [5].

Krueger et al., [8] attempted to consolidate the theories of entrepreneurial intentions by testing both the theories, TPB and SEE; however attempt was not made to integrate both. Krueger [16] argued that attitude variable in the TPB model encompasses the idea of perceived desirability in SEE model, the subjective norm corresponds to desirability and feasibility and perceived feasibility represents perceived behaviour control. 
Shapero and Sokol, Bird, Krueger and Kolvereid [17] have recognized the key role that entrepreneurial intent plays. Researchers suggested that for the entrepreneurial process, some of the pre-requisite steps that are especially important include the existence of business opportunity, identification of the opportunity by the entrepreneur, and most importantly the conscious decision to exploit the opportunity. Contrary to this, Krueger [8] argued that it is the individual intention to identify or lay hands on the opportunity, but the entrepreneurial process tends to be an individual's idea or plan.

Based on the cited literature and subsequent interpretations, this study was conducted to analyze the entrepreneurial intentions of the students studying management program with respect to the components of the Shapero's model of Entrepreneurial Intentions. The following set of hypothesis was developed to test based on the literature and the conclusions drawn from the model:

Hypothesis 1: Positive impact of perceived desirability on the management student's entrepreneurial intentions.

Hypothesis 2: Positive impact of perceived feasibility on the management student's entrepreneurial intentions.

Hypothesis 3: Positive impact of Propensity to Act on the management student's entrepreneurial intentions.

\section{Methodology}

Taking the scholars of post graduate program at one of the management institutes at Ahmedabad as the base population, this study aims to analytically explain the Entrepreneurial Intentions of these students. In this context, the Entrepreneurial Intentions of the management students represent the dependent variable while the other three components of Shapero's model such as Perceived Desirability, Perceived Feasibility and Propensity to Act serve as the independent variables. Independent variables have been tested to assess their influence on the entrepreneurial intentions.

\subsection{Data Collection}

A structured questionnaire was designed as the main tool for data collection in the study. The first part of the questionnaire was to get the demographic characteristics such as gender, age, stream in graduation, specialization in MBA, whether they possess any experience and if they come from the business family. The second part of the questionnaire consisted of the variables used in the model covering various dimensions of Perceived Desirability, Perceived Feasibility, Entrepreneurial Intentions and Propensity to Act. The number of items presented for each dimension is four. These statements were measured on a five point $\mathrm{Li}$ kert scale with agreement on $1=$ Strongly Disagree to $5=$ Strongly Agree or possibility to the degree of extent as $1=$ no extent to $5=$ very great extent. Data was collected from 125 students studying Post Graduate Program in Management at ICFAI Business School, Ahmedabad, Gujarat State in India. 
Descriptive Survey design was used to collect the data. The target population for the study comprises of the students pursuing management education, both senior and junior batch students, thus the sample accounts to 125 students. The demographic characteristics of the population are given in Table 1.

\subsubsection{Demographic Analysis of the Sample Population}

The population consisted of $66 \%$ boys and $34 \%$ girls with $25 \%$ in the age of 20 21 and 54\% in the age of $22-23$ and others above 24 years of age. Out of these, $78 \%$ of the students have come from commerce background and $16 \%$ were engineering graduates. In all, $46 \%$ of the students have selected Marketing as their specialization in the program and $43 \%$ opted for Finance specialization and others were from $\mathrm{HR}$ and Operations specializations. It was identified that $80 \%$ of the students did not have experience and $57 \%$ students have come from business families.

\section{Results \& Discussion}

The data was analyzed using SPSS package and the results are discussed in the following headings:

\subsection{Descriptive Analysis of Independent Variables}

The study was to investigate the level of agreement of the students for the statements Table 1. Demographic profile of respondents.

\begin{tabular}{|c|c|c|c|}
\hline Variable & Dimension & Frequency & Percentage \\
\hline \multirow{2}{*}{ Gender } & Boys & 83 & 66.4 \\
\hline & Girls & 42 & 33.6 \\
\hline \multirow{4}{*}{ Age } & $20-21$ & 31 & 24.8 \\
\hline & $22-23$ & 67 & 53.6 \\
\hline & $24-25$ & 22 & 17.6 \\
\hline & $26 \&$ above & 5 & 0.04 \\
\hline \multirow{4}{*}{ Degree } & Arts & 5 & 4.0 \\
\hline & Commerce & 97 & 77.6 \\
\hline & Engineering & 20 & 16.0 \\
\hline & Medical & 3 & 2.4 \\
\hline \multirow{4}{*}{ Specialization in MBA } & Marketing & 57 & 45.6 \\
\hline & Finance & 54 & 43.2 \\
\hline & Operations & 2 & 1.6 \\
\hline & HR & 12 & 9.6 \\
\hline \multirow{2}{*}{ Experience } & Yes & 25 & 20.0 \\
\hline & No & 100 & 80.0 \\
\hline \multirow{2}{*}{ Business Family } & Yes & 71 & 56.8 \\
\hline & No & 54 & 43.2 \\
\hline
\end{tabular}


pertaining to the perceived desirability. The results in Table 2 indicated that the respondents have shown interest that if opportunity and resources are available, they would like to be entrepreneurs ( $\bar{X}=3.82$ ). They also strongly felt that being an entrepreneur gives them great satisfaction as indicated by the mean of 3.71 . They are excited to become the entrepreneurs $(\bar{X}=3.54)$ and consider that being an entrepreneur, they have several advantages $(\bar{X}=3.30)$.

The results in Table 3 indicated the extent of agreement of the respondents to the statements pertaining to the Perceived Feasibility of being entrepreneurs. It indicated that students have strongly agreed that it is enthusiastic to take up entrepreneurship as their career $(\bar{X}=3.85)$ and they also felt and agreed that trust of their family or friends in their ability, whether they can be successful as an entrepreneur is important $(\bar{X}=3.66)$. They have also expressed that they would like to have complete control over the situation once they start their own business venture ( $\bar{X}=3.53$ ). It was also found to be in agreement to a significant extent that they had the knowledge and complete practical details as to how to start their own business ( $\bar{X}=3.48$ ).

The study was conducted to find out as to what extent the students would carry out the behaviours to start their own business ventures (Table 4). Majority of the students were in agreement only to a moderate extent for the operations, expansion, research and innovation. However, it was felt by few students that introducing products regularly for customers will develop their business to a great extent $(\bar{X}=3.18)$. It was shown that bringing in the latest processes and systems into production will enhance their business to a great extent $(\bar{X}=$ 2.78). Research and development has been found to be important to a great extent to develop new products and services, and in turn to grow the business $(\bar{X}$

Table 2. Perceived desirability of entrepreneurship.

\begin{tabular}{cccccccc}
\hline Dimension & $\begin{array}{c}\text { Strongly } \\
\text { Disagree }\end{array}$ & Disagree & Undecided & Agree & $\begin{array}{c}\text { Strongly } \\
\text { Agree }\end{array}$ & Mean & SD \\
\hline Satisfaction & 4 & 14 & 28 & 47 & 32 & 3.71 & 1.069 \\
Advantages & 8 & 22 & 39 & 36 & 20 & 3.30 & 1.130 \\
Opportunity & 8 & 11 & 24 & 35 & 47 & 3.82 & 1.214 \\
Excitement & 10 & 18 & 31 & 25 & 41 & 3.54 & 1.317 \\
\hline
\end{tabular}

Source: Primary Data collected by the Authors.

Table 3. Perceived feasibility of entrepreneurship.

\begin{tabular}{cccccccc}
\hline Dimension & $\begin{array}{c}\text { Strongly } \\
\text { Disagree }\end{array}$ & Disagree & Undecided & Agree & $\begin{array}{c}\text { Strongly } \\
\text { Agree }\end{array}$ & Mean & SD \\
\hline Trust & 6 & 12 & 35 & 38 & 34 & 3.66 & 1.122 \\
Knowledge & 6 & 16 & 41 & 36 & 26 & 3.48 & 1.104 \\
Control & 8 & 18 & 36 & 26 & 37 & 3.53 & 1.235 \\
Enthusiasm & 7 & 12 & 25 & 30 & 51 & 3.85 & 1.219 \\
\hline
\end{tabular}

Source: Primary Data collected by the Authors. 
$=2.57)$. They also indicated that expanding the business can have fast track development in their business as depicted with a mean of 2.14.

These results are in alignment with the studies conducted by [16]. It established the fact that with the lower extent of predisposition to act, the entrepreneurial intentions were not likely to develop and the sole predictor of entrepreneurial intentions will be perceived desirability.

\subsection{Descriptive Analysis of Dependent Variable}

The dependent variable, Entrepreneurial Intention was measured with four items. The results from Table 5 indicated that majority of the students were willing to make their efforts to the maximum extent to be successful entrepreneurs $(\bar{X}=3.83)$ and all of them had shown determination to the highest degree $(\bar{X}=3.78)$. They were all willing to take up entrepreneurship as their career with a mean of 3.50 and eventually achieve their goal.

\subsection{Scale Validity and Reliability Analysis}

Reliability and Consistency test using Cronbach Alpha was subjected to analysis before examining the relationships between the Shapero's model and the entrepreneurial intentions. The Cronbach alpha coefficient for the complete set was 0.835 and for independent variables, it ranged from 0.874 to 0.917 of the questionnaire, which indicates high internal consistency and alpha was above 0.7 as recommended by [18].

The Skewness and Kurtosis (Table 6) was measured for both dependent and independent variables and were found within the normal range [19]. Significantly high positive correlation was found between the dependent and independent

Table 4. Propensity to Act and the behaviours to develop business.

\begin{tabular}{cccccccc}
\hline & No Extent Little Extent & $\begin{array}{c}\text { Moderate } \\
\text { Extent }\end{array}$ & $\begin{array}{c}\text { Great } \\
\text { extent }\end{array}$ & $\begin{array}{c}\text { Very Great } \\
\text { Extent }\end{array}$ & Mean & SD \\
\hline Operations & 34 & 47 & 37 & 6 & 1 & 2.14 & 0.904 \\
Expansion & 6 & 41 & 57 & 16 & 5 & 2.78 & 0.876 \\
Research & 19 & 34 & 55 & 16 & 1 & 2.57 & 0.928 \\
Innovation & 9 & 17 & 56 & 29 & 14 & 3.18 & 1.040 \\
\hline
\end{tabular}

Source: Primary Data collected by the Authors.

Table 5. Descriptive analysis of entrepreneurial intentions.

\begin{tabular}{cccccccc}
\hline & No Extent & $\begin{array}{c}\text { Little } \\
\text { Extent }\end{array}$ & $\begin{array}{c}\text { Moderate } \\
\text { Extent }\end{array}$ & $\begin{array}{c}\text { Great } \\
\text { extent }\end{array}$ & $\begin{array}{c}\text { Very Great } \\
\text { Extent }\end{array}$ & Mean & SD \\
\hline Readiness & 11 & 12 & 35 & 37 & 30 & 3.50 & 1.209 \\
Goal & 9 & 21 & 41 & 29 & 25 & 3.32 & 1.182 \\
Effort & 5 & 16 & 20 & 38 & 46 & 3.83 & 1.176 \\
Determination & 4 & 14 & 31 & 33 & 43 & 3.78 & 1.135 \\
\hline
\end{tabular}

Source: Primary Data collected by the Authors. 
variables with strongest relationship between desirability and the entrepreneurial intentions $(r=0.709)$. Significantly strong association between all the variables illustrates that all the variables are integrated and associated in influencing the entrepreneurial intentions.

\subsection{PLS (SEM) Regression Analysis}

Data was analyzed for Partial Linear Squares Regression Analysis to find out the relationship between the independent variables Perceived Desirability, Perceived Feasibility and Propensity to Act against Entrepreneurial Intentions among the students pursuing management program.

Results from Table 7, latent factors explain the percentage of variance accounted for by the independent variables. For latent factor 1, 85.5\% variance is explained by Perceived Desirability (first independent variable) and $86.6 \%$ by the entrepreneurial intentions (dependent variable). In the second and third factors, the variance explained by $\mathrm{X}$ and $\mathrm{Y}$ are lesser. Hence the first model of factor 1 explaining $\mathrm{X}$ and $\mathrm{Y}$ relationship, which has higher variance explained, can be considered.

Table 8 depicts the estimated regression coefficient of each independent variable for predicting entrepreneurial intentions. The results indicate that Perceived

Table 6. Pearson correlation coefficient.

\begin{tabular}{ccccccc}
\hline Variables & Feasibility & Desirability & Propensity & Intention & Skewness & Kurtosis \\
\hline FEASIBILITY & 1 & & & & -0.498 & -0.418 \\
DESIRABILITY & $0.655^{* *}$ & 1 & & & -0.533 & -0.371 \\
PROPENSITY & $0.599^{* *}$ & $0.709^{* *}$ & 1 & & -0.482 & -0.408 \\
INTENTION & $0.659^{* *}$ & $0.642^{* *}$ & $0.540^{* *}$ & 1 & -0.513 & -0.317 \\
\hline
\end{tabular}

**. Correlation is significant at the 0.01 level.

Table 7. Proportion of variance explained by TPB constructs.

\begin{tabular}{cccccc}
\hline \multirow{2}{*}{$\begin{array}{c}\text { Latent } \\
\text { Factors }\end{array}$} & $\begin{array}{c}\text { X Variance } \\
\text { Explained }\end{array}$ & $\begin{array}{c}\text { Cum. X Variance } \\
\text { Explained }\end{array}$ & $\begin{array}{c}\text { Y Variance } \\
\text { explained }\end{array}$ & $\begin{array}{c}\text { Cum. Y Var (R } \\
\text { Square) }\end{array}$ & $\begin{array}{c}\text { Adjusted R } \\
\text { Square }\end{array}$ \\
\hline 1 & 0.855 & 0.855 & 0.866 & 0.866 & 0.847 \\
2 & 0.081 & 0.936 & 0.021 & 0.887 & 0.852 \\
3 & 0.064 & 1.000 & 0.103 & 0.99 & 0.849 \\
\hline
\end{tabular}

Table 8. Regression coefficients.

\begin{tabular}{cccc}
\hline TPB Constructs & Regression Coefficient & t-value & Sig. \\
\hline Constant & 0.714 & & \\
Perceived Feasibility & 0.334 & 5.42 & 0.000 \\
Propensity to Act & 0.210 & 5.91 & 0.000 \\
Perceived Desirability & 0.612 & 6.46 & 0.000 \\
\hline
\end{tabular}


Desirability has the highest regression coefficient (0.612) which has impact on the entrepreneurial intentions followed by Perceived Feasibility and Propensity to Act. The Propensity to Act does not have much impact on the entrepreneurial intentions.

Taking all the factors into account and constant at zero, the entrepreneurial intention is 0.714 . With all the independent variables at zero, a unit increase in Perceived Desirability will lead to 0.334 increase in the entrepreneurial intentions; a unit increase in Propensity to Act will lead to 0.21 and a unit increase in Perceived Desirability will lead to 0.612 increase in entrepreneurial intentions respectively, which is an indication that Perceived Desirability and Perceived Feasibility have greater influence on the intentions of the students. Propensity to Act does not have much influence on the entrepreneurial intentions which is in agreement with the study conducted by Krueger.

Table 9 shows the importance of TPB constructs in a given factor. In all the latent factors, Perceived Desirability has the highest value (1.068) followed by Perceived Feasibility and Propensity to Act.

The relationship between variables and factors is given in Table 10. Results infer that perceived desirability, perceived feasibility and propensity to act and entrepreneurial intentions have positive relationship with factor 1 and similarly with factor 2 and 3 respectively, whereas the propensity to act has a negative relationship with factor 2 and 3.

\section{Conclusions}

The study was set out to analyze the entrepreneurial intentions of the students pursuing management program at a business school in Ahmedabad with the application of the Shapero's Model of Entrepreneurial Intentions as the basis. The independent variables viz., perceived desirability, perceived feasibility and propensity

Table 9. Variable importance in the projection.

\begin{tabular}{cccc}
\hline Variables & \multicolumn{3}{c}{ Latent Factors } \\
\cline { 2 - 4 } & 1 & 2 & 3 \\
\hline Perceived Feasibility & 0.952 & 0.910 & 0.983 \\
Propensity to Act & 0.921 & 0.907 & 0.915 \\
Perceived Desirability & 1.068 & 1.047 & 1.059
\end{tabular}

Table 10. Weights.

\begin{tabular}{cccc}
\hline Variables & \multicolumn{3}{c}{ Latent Factors } \\
\cline { 2 - 4 } & $\mathbf{1}$ & $\mathbf{2}$ & $\mathbf{3}$ \\
\hline Perceived Feasibility & 0.612 & 0.378 & 0.653 \\
Propensity to Act & 0.598 & -0.452 & -0.692 \\
Perceived Desirability & 0.699 & 0.901 & 0.144 \\
Entrepreneurial Intensions & 0.551 & 0.298 & 0.049
\end{tabular}


to act were expected to influence the students.

The descriptive analysis of data indicated that the students had shown greater interest in becoming entrepreneurs and the career of entrepreneurship was perceived more attractive by them, by virtue of the potential advantages to them. The idea of being an entrepreneur gives them lot of satisfaction as they believe they can provide employment to others and also contribute to the growth of the nation. They had significant enthusiasm towards entrepreneurship coupled with the confidence that innovating and introducing new products for customers, introducing new systems and process and expanding the firm etc. will have bearing on the development of their business. The study also has revealed that economic opportunity to start their own business is very important for them. Authority and autonomy plays a very significant role in their decision making.

The correlation analysis indicated a strong positive relationship between all dependent and independent variables. However perceived desirability had the strongest relationship with entrepreneurial intentions indicating that the willingness or desire to take up entrepreneurship was the key determinant in the process of making the decision to be an entrepreneur. This was further investigated with the application of partial least squares regression analysis.

The results from the partial least squares (SEM) regression analysis indicated that the entrepreneurial intentions of the students were predicted significantly by the independent variables of the model. However, Perceived Desirability has the overriding impact on the entrepreneurial intentions (having a high regression coefficient) followed by Perceived Feasibility. It can be concluded that students possess attitude and dispositions towards becoming entrepreneurs which affect their intention positively. All of the three hypotheses are supported by the results. However, results have shown that the lesser the predisposition to act, lesser is the probability that entrepreneurial intentions will not develop and the sole predictor has been the perceived desirability as supported by study conducted by [16].

It is recommended that the business school where the students are pursuing their management program should emphasize more on entrepreneurship related courses and introduce specialized modules to impart essential skills and knowledge. This would enable the students to develop interest and acquire the relevant skills and competencies essential for an entrepreneur who in turn would contribute in strengthening the socio-economic firmament of the nation.

The sample size was small and the data was collected from a particular institution to draw inferences to understand the entrepreneurial intentions of the students. This served as a limitation, albeit the study can be further extended to more number of institutions, taking a larger sample into consideration. Accordingly, the inferences could be substantiated further.

\section{Conflicts of Interest}

The authors declare no conflicts of interest regarding the publication of this paper. 


\section{References}

[1] Ajzen, I. (1987) Attitudes, Traits and Actions: Dispositional Prediction of Behavior in Social Psychology. Advances in Experimental Social Psychology, 20, 1-63. https://doi.org/10.1016/S0065-2601(08)60411-6

[2] Shapero, A. and Sokol, L. (1982) The Social Dimensions of Entrepreneurship. In: Shapero, A., Ed., The Encyclopedia of Entrepreneurship, Prentice Hall, Englewood Cliffs, 72-90.

[3] Bird, B. (1988) Implementing Entrepreneurial Ideas: The Case for Intentions. Academy of Management Review, 13, 442-454. https://doi.org/10.5465/amr.1988.4306970

[4] Boyd, N.G. and Vozikis, G.S. (1994) The Influence of Self-Efficacy on the Development of Entrepreneurial Intentions and Actions. Entrepreneurship Theory and Practice, 18, 63. https://doi.org/10.1177/104225879401800404

[5] Krueger, N.F. and Brazeal, D.V. (1994) Entrepreneurial Potential and Potential Entrepreneurs. Entrepreneurship Theory and Practice, 18, 91. https://doi.org/10.1177/104225879401800307

[6] Ajzen, I. (1991) The Theory of Planned Behavior. Organizational Behavior and Human Decision Processes, 50, 179-211. https://doi.org/10.1016/0749-5978(91)90020-T

[7] Urban, B. (2010) A Gender Perspective on Career Preferences and Entrepreneurial Self-Efficacy. SA Journal of Human Resource Management, 8, 1-8. https://doi.org/10.4102/sajhrm.v8i1.293

[8] Krueger, N.F.J., Reillly, M.D. and Carsrud, A.L. (2000) Competing Models of Entrepreneurial Intentions. Journal of Business Venturing, 15, 411-432. https://doi.org/10.1016/S0883-9026(98)00033-0

[9] Peng, Z., Lu, G. and Kang, H. (2012) Entrepreneurial Intentions and Its Influencing Factors: A Survey of the University Students in Xi'an China. Creative Education, 3, 95-100. https://doi.org/10.4236/ce.2012.38B021

[10] Liñán, F. (2008) Skill and Value Perceptions: How Do They Affect Entrepreneurial Intentions? International Entrepreneurship and Management Journal, 4, 257-272. https://doi.org/10.1007/s11365-008-0093-0

[11] Ahmad, S.Z., Jabeen, F. and Khan, M. (2014) Entrepreneurs Choice in Business Venture: Motivations for Choosing Home-Stay Accommodation Businesses in Peninsular Malaysia. International Journal of Hospitality Management, 36, 31-40. https://doi.org/10.1016/j.ijhm.2013.08.006

[12] Kim, J. (2017) Building a Dynamic Model of Entrepreneurial Intention Formation in Sharing Economy Platform: The Resource-Based Theory Approach. Graduate Theses and Dissertations, Iowa State University.

[13] Krueger, N.F., Relly, M.D. and Carsrud, A.L. (2000) Competing Models of Entrepreneurial Intentions. Journal of Business Venturing, 15, 411-432.

[14] Veciana, J.M., Aponte, M. and Urbano, D. (2005) University Students' Attitudes towards Entrepreneurship: A Two Countries Comparison. The International Entrepreneurship and Management Journal, 1, 165-182. https://doi.org/10.1007/s11365-005-1127-5

[15] Peterman, N.E. and Kennedy, J. (2003) Enterprise Education: Influencing Students' Perceptions of Entrepreneurship. Entrepreneurship Theory and Practice, 28, 129-144. https://doi.org/10.1046/j.1540-6520.2003.00035.x

[16] Krueger, N. (1993) The Impact of Prior Entrepreneurial Exposure on Perceptions of New Venture Feasibility and Desirability. Entrepreneurship: Theory \& Practice, 18, 
5. https://doi.org/10.1177/104225879301800101

[17] Kolvereid, L. (1996) Prediction of Employment Status Choice Intentions. Entrepreneurship Theory and Practice, 21, 47-57. https://doi.org/10.1177/104225879602100104

[18] Nunnally, J. (1978) Psychometric Methods.

[19] Tabachnick, B.G., Fidell, L.S. and Osterlind, S.J. (2001) Using Multivariate Statistics. 5th Edition, Haper and Row, New York. 